\title{
Human giant congenital melanocytic nevus exhibits potential proteomic alterations leading to melanotumorigenesis
}

Hyoung Kyu Kim', Yong Kyu Kim²†, In-Sung Song ${ }^{1+}$, Sung-Ryul Lee', Seung Hun Jeong ${ }^{1}$, Min Hee Kim', Dae Yun Seo ${ }^{1}$, Nari Kim¹, Byoung Doo Rhee', Kyoung Soo Ko', Kwan Chul Tark ${ }^{3}$, Chul Gyoo Park', Je-Yoel $\mathrm{Cho}^{5}$ and Jin $\mathrm{Han}^{1 *}$

\begin{abstract}
Background: A giant congenital melanocytic nevus (GCMN) is a malformation of the pigment cells. It is a distress to the patients for two reasons: one is disfigurement, and the other is the possibility of malignant changes. However, the underlying mechanisms of the development of GCMN and melanotumorigenesis in GCMN are unknown. Hence, the aim of this study was to identify the proteomic alterations and associated functional pathways in GCMN.

Results: Proteomic differences between GCMN $(n=3)$ and normal skin samples $(n=3)$ were analyzed by one-dimensional-liquid chromatography-tandem mass spectrometry Relative levels of the selected proteins were validated using western blot analysis. The biological processes associated with the abundance modified proteins were analyzed using bioinformatic tools. Among the 46 abundance modified proteins, expression of 4 proteins was significantly downregulated and expression of 42 proteins was significantly upregulated in GCMN compared to normal skin samples $(p<0.05)$. More importantly, $31 \%$ of the upregulated proteins were implicated in various cancers, with five proteins being specifically related with melanoma. The abundance modified proteins in GCMN were involved in the biological processes of neurotrophin signaling, melanosome, and downregulated of MTA-3 in ER-negative breast tumors. In particular, an increase in the expression of the 14-3-3 protein family members appeared to be associated with key cellular biological functions in GCMN. Western blot analysis confirmed the upregulation of 14-3-3epsilon, 14-3-3 tau, and prohibitin in GCMN.
\end{abstract}

Conclusion: These findings suggest that GCMN exhibits potential proteomic alterations, which may play a role in melanotumorigenesis, and the significant alteration of 14-3-3 family proteins could be a key regulator of the biological pathway remodeling in GCMN.

Keywords: Giant congenital melanocytic nevi, Melanotumorigenesis, Proteomics, 14-3-3 epsilon, 14-3-3 tau, Systemic analysis

\footnotetext{
*Correspondence: phyhanj@inje.ac.kr

${ }^{\dagger}$ Equal contributors

${ }^{1}$ National Research Laboratory for Mitochondrial Signaling, Department of Physiology, College of Medicine, Cardiovascular and Metabolic Disease Center, Inje University, Busan, Korea

Full list of author information is available at the end of the article
} 


\section{Background}

Congenital melanocytic nevi (CMN) are pigment cell malformations that are visible at birth, or are nevi showing congenital features that become clinically obvious shortly after birth [1]. CMN is caused by abnormal melanocyte differentiation, migration, and deposition in the dermis during the early stages of embryogenesis [2,3]. It is a distress to patients for two reasons: one is disfigurement, and the other is the increased risk of developing malignant melanoma $[3,4]$, especially in individuals with giant congenital melanocytic nevi (GCMN; over $20 \mathrm{~cm}$ in diameter) [5]. Several genomic and proteomic studies have been performed to elucidate the mechanism of melanotumorigenesis arising from CMN. Gene-based analyses have revealed that the oncogenic $B R A F[6]$ and NRAS [7] mutations are frequently seen in CMN. Additionally, increased Bcl-2 expression in CMN has been suggested to suppress apoptosis, which otherwise plays an important role in the maintenance of nevocytes [8]. In spite of these findings, the major biological processes and pathways of melanotumorigenesis remain unclear. Therefore, the complete proteomic characterization of GCMN and related biological pathways through comparative protein profiling is essential to understand the underlying mechanism of the origin of GCMN and the subsequent process of melanotumorigenesis.

In this study, the proteomic alteration and systemic properties of GCMN were assessed, with the aim of gaining an insight into the functional association between GCMN and melanotumorigenesis. We used labelfree liquid chromatography-mass spectrometry (LC-MS) and established bioinformatic tools to identify the proteins that may play a key role in the malignant transformation of GCMN. We found that the 46 proteins were changed in protein abundance levels between normal skin and GCMN samples, and these proteins belonged to tightly organized functional clusters. Moreover, we found that five of the identified proteins were implicated in melanoma. The results of this study will improve our understanding in the biological identification of GCMN and the possible mechanisms that give rise to GCMN-associated melanotumorigenesis.

\section{Results}

\section{Characteristics of the study population}

The clinical characteristics of patients who provided GCMN and normal skin samples are listed in Table 1. All GCMN were over $20 \mathrm{~cm}$ in diameter. A representative GCMN lesion in a patient is shown in Figure 1A. To minimize environmental bias between individuals, we collected three paired normal and GCMN skin samples from three GCMN donors for one-dimensional-liquid chromatography-tandem mass spectrometry (1D-LCMS/MS) analysis (Table 1). Seven unpaired samples from
Table 1 Clinical characteristics of GCMN and normal skin samples

\begin{tabular}{|c|c|c|c|c|}
\hline Sample ID & Age, yr & Gender & Location & Experiment \\
\hline \multicolumn{5}{|l|}{ Normal } \\
\hline Normal $1^{*}$ & 8 & Male & Face & LC-MS \\
\hline Normal 2* & 5 & Female & Face & LC-MS \\
\hline Normal $3^{*}$ & 6 & Female & Face & LC-MS \\
\hline Normal 4 & 14 & Female & Forehead & Western blot \\
\hline Normal 5 & 11 & Female & Face & Western blot \\
\hline Normal 6 & 19 & Female & Forehead & Western blot \\
\hline Normal 7 & 36 & Female & Face & Western blot \\
\hline Normal 8 & 18 & Female & Face & Western blot \\
\hline Normal 9 & 21 & Female & Face & Western blot \\
\hline Normal 10 & 40 & Female & Face & Western blot \\
\hline \multicolumn{5}{|l|}{ GCMN } \\
\hline GCMN 1 & 8 & Male & Face & LC-MS \\
\hline GCMN 2 & 5 & Female & Face & LC-MS \\
\hline GCMN 3 & 6 & Female & Face & LC-MS \\
\hline GCMN 4 & 8 & Male & Forehead & Western blot \\
\hline GCMN 5 & 6 & Female & Abdomen & Western blot \\
\hline GCMN 6 & 3 & Female & Left leg & Western blot \\
\hline GCMN 7 & 3 & Male & Face & Western blot \\
\hline GCMN 8 & 6 & Female & Forehead & Western blot \\
\hline GCMN 9 & 7 & Male & Abdomen & Western blot \\
\hline GCMN 10 & 6 & Female & Head & Western blot \\
\hline
\end{tabular}

* Normal skin samples excised from GCMN patient ID 1, 2, 3 .

normal skin and GCMN were used for western blot analysis to validate the proteomic results. The average age of GCMN patients who donated samples for western blot analysis was lower $(5.57 \pm 1.90)$ than that of the normal skin donors $(22.71 \pm 11.01, \mathrm{p}=0.0058, \mathrm{n}=7)$.

\section{Proteomic alterations in GCMN}

The same amount $(20 \mu \mathrm{g})$ of soluble proteins obtained from GCMN and normal skin samples were analyzed on sodium dodecyl sulfate polyacrylamide gel electrophoresis (SDS-PAGE; Figure 1B). The Coomassie bluestained gels were sliced into 15 uniform slices. The total ion current chromatogram of each slice was acquired (Additional file 1: Figure S1), which led to the identification of 438 non-redundant proteins (Additional file 2: Table S2). Among these, 343 proteins were commonly identified in both the groups, 62 proteins were detected only in GCMN samples, and 33 proteins were detected only in normal skin samples (Figure 1C). Forty-six abundance modified proteins were identified whose protein abundance level was significantly (Student's t-test with Bonferroni correction, $\mathrm{p}<0.05)$ different between GCMN and normal skin (Figure 1D). The large majority of these abundance modified proteins were upregulated 

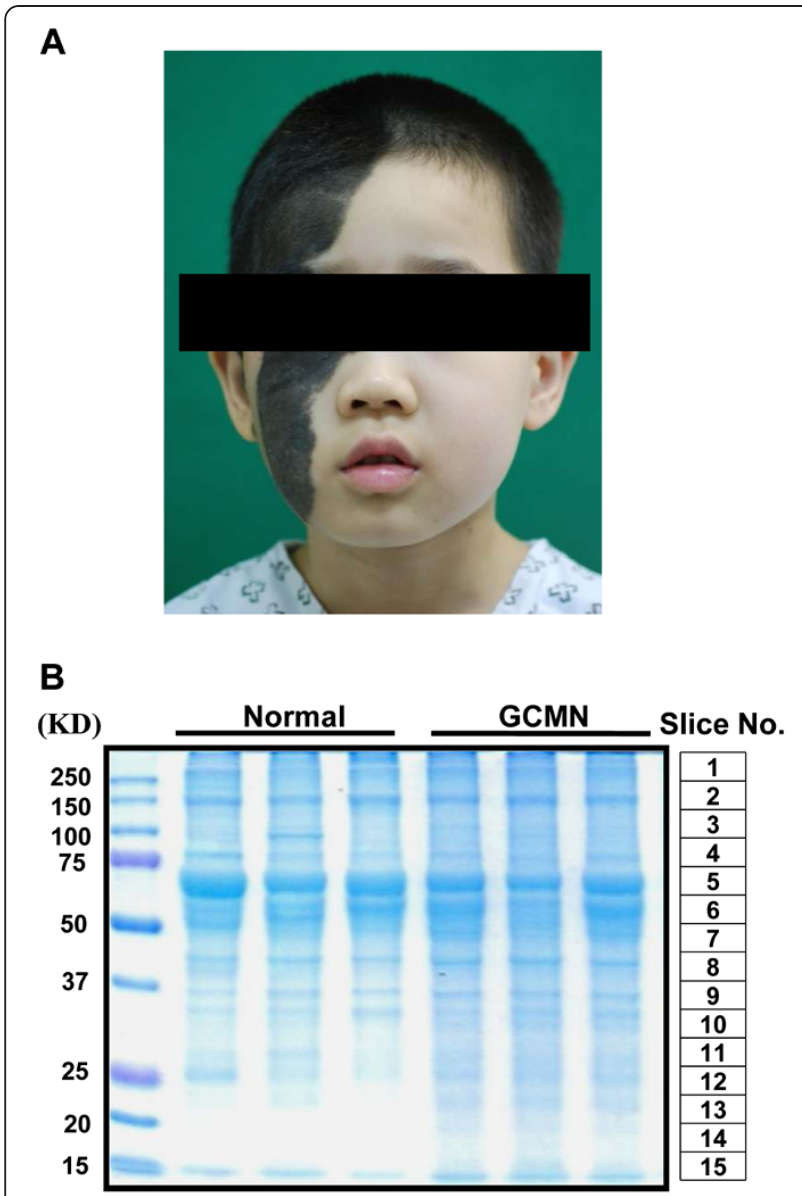

C

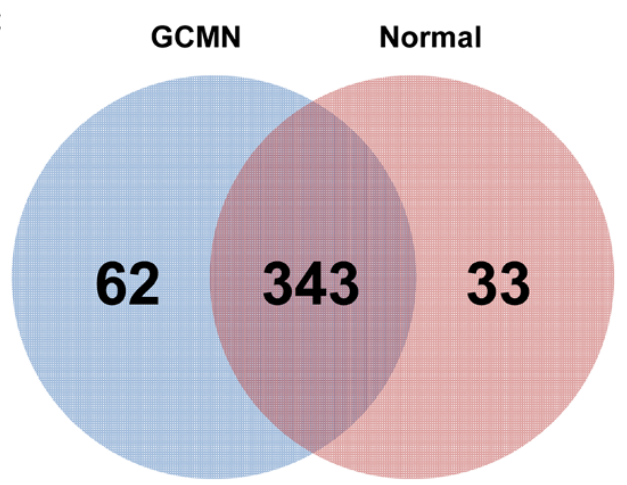

Figure 1 Comparative proteomic analysis of giant congenital melanocytic nevi (GCMN) and normal skin samples using one-dimensional-liquid chromatography-electrospray ionization-tandem mass spectrometry. (A) A representative GCMN lesion of a donor patient (B) Coomassie-stained gel of normal skin and GCMN proteins ( $n=3$ each). Slice number indicates the matching mass peak result in Additional file 1: Figure S1. (C) Venn diagram of the identified proteins in normal and GCMN skin samples.

(42 of 46, 91.3\%), and very few (4 proteins, $8.7 \%$ ) were downregulated in GCMN (Figure 2, Table 2). The most upregulated protein in GCMN was cathepsin D (CTSD) [GenBank Gene ID: 1509], which was expressed at a 6.8- fold higher level than in normal skin. In addition, protein disulfide-isomerase A3 precursor (PDIA3, 5.4-fold) [GenBank Gene ID: 2923], prohibitin (PHB, 5.3-fold) [GenBank Gene ID: 5245], heat-shock protein 70 (5.2fold) [GenBank Gene ID: 3312], D-3-phosphoglycerate dehydrogenase (5-fold) [GenBank Gene ID: 26227], and adenosine-5'-triphosphate synthase subunit beta (5-fold) [GenBank Gene ID: 506] were highly (>4-fold) upregulated in GCMN. The 4 proteins downregulated in GCMN were cytokeratin-1 (-1.4-fold) [GenBank Gene ID: 3848], filaggrin 2 (-4.7-fold) [GenBank Gene ID: 388698], hornerin (-6.0-fold) [GenBank Gene ID: 388697], and alcohol dehydrogenase 1B (-6.2-fold) [GenBank Gene ID: 125]. Interestingly, we found that $33 \%$ (14 of total 42 ) of the significantly upregulated proteins in GCMN samples were implicated in various kinds of cancers (Table 2). Five of the 14 proteins, namely CTSD [GenBank Gene ID: 1509][9,10], PHB [GenBank Gene ID: 5245][11,12], chondroitin sulfate proteoglycan 4 [GenBank Gene ID: 1464] [13], phosphatidylethanolamine-binding protein 1 [GenBank Gene ID: 5037] [14], and ribosomal protein SA [GenBank Gene ID: 3921] [15] were related with melanoma.

\section{Systemic properties of the altered GCMN proteome}

Proteomic profiling of certain diseases has been increasingly used to acquire data on a large number of proteins to identify potential biomarkers and to gain insight into the underlying mechanisms of a variety of diseases. However, the massive amount of generated information often only increases the complexity of these analyses. To address this issue, we developed a systemic approach to analyze the proteomic data generated in the present study. To gain an insight into the systemic properties of the GCMN proteome, the 46 abundance modified proteins were categorized based on molecular function, biological process, and Clusters of Orthologous Groups of proteins (COG) analysis. The proteins were classified into the following classes according to their molecular functions: chaperones (16\% of total), oxidoreductases (8\%), and cytoskeletal elements (7\%) (Figure 3A). Proteins associated with the biological processes of signal transduction (15\%), cell structure and motility (10\%), protein metabolism and modification (10\%), and cell cycle $(10 \%)$ were markedly altered in their expression. The COG analysis showed that the altered proteins in GCMN samples were involved in posttranslational modification, turnover, chaperones (30\%), and the cytoskeleton (12\%; Figure $3 \mathrm{C}$ ), which was consistent with the molecular function and biological process classification.

Further network analysis was carried out using the software tool, ClueGO, to identify enriched functional groups in the GCMN samples and obtain detailed information on each one. Gene Ontology (GO)_biological 


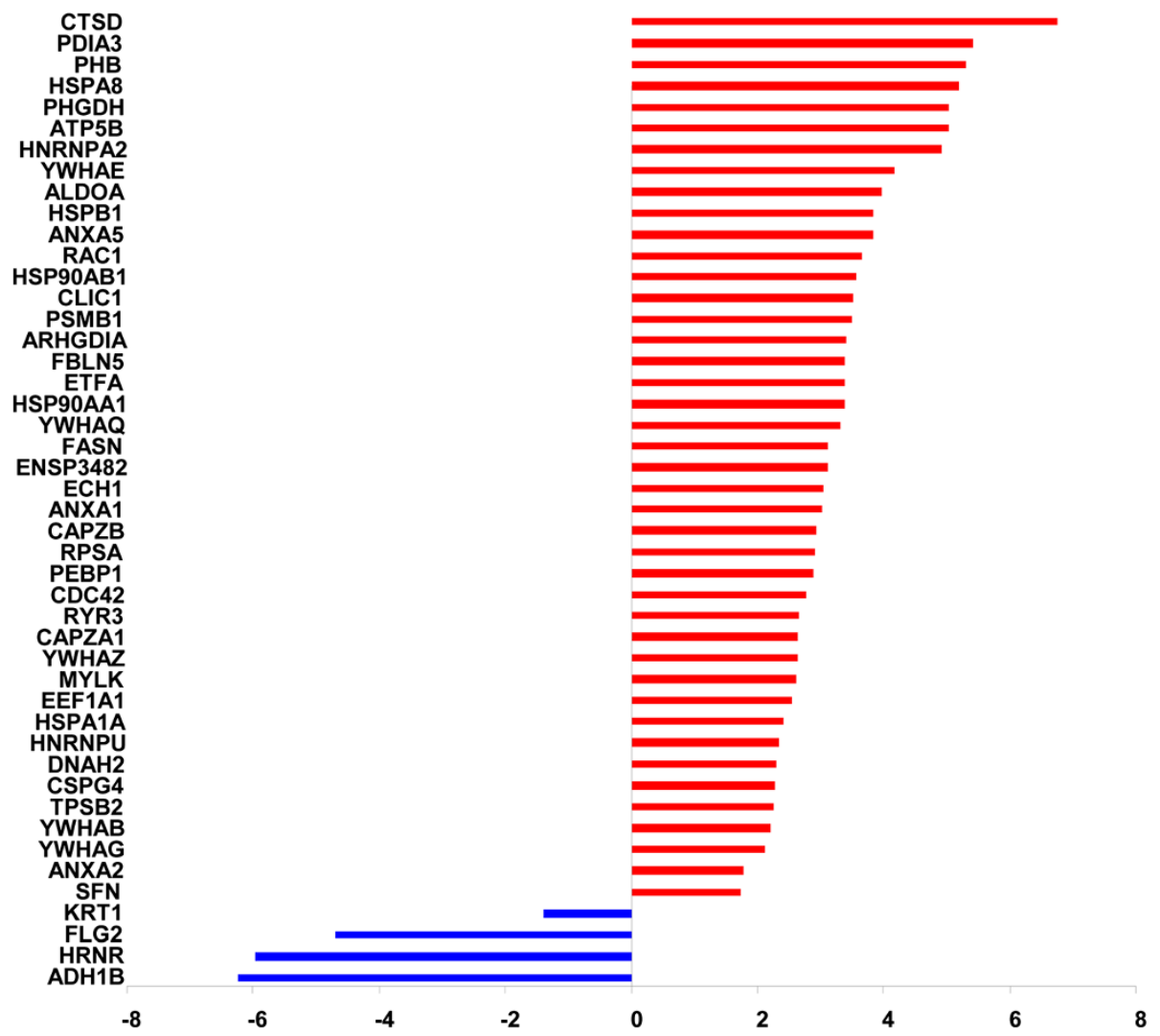

Figure 2 Fold-changes in abundance modified proteins in GCMN compared to normal skin. The histogram displays the protein symbol and the averaged fold-change of each differentially expressed protein in GCMN. A total of 46 proteins were differentially expressed, with 4 proteins downregulated and 42 upregulated in GCMN compared to normal skin.

process, GO_cellular component, GO_molecular function, KEGG pathway, and Reactome_biocarta were selected as ontology sources. The specific functional groups identified as significantly enriched in GCMN were melanosome (GO_cellular component), neurotrophin signaling pathway (KEGG pathway), downregulated of MTA-3 in ER-negative breast tumors (Biocarta), cell cycle (KEGG pathway), phospholipase inhibitor activity (GO_molecular function), and glycolysis/gluconeogenesis (KEGG pathway; Table 3, Additional file 3: Figure S2).

Because proteins rarely act alone, but rather interact as a group, thus comprising a functional cluster, a protein-protein interacting network was constructed using STRING 8.0. This network consisted of 45 of the 46 abundance modified proteins, with 52 interactions between them. In the GCMN network, the upregulated proteins were tightly linked with each other, forming a large cluster. The biological meaning of the cluster was determined by overlaying the COG of each protein on the network, which revealed shared COGs between close neighboring proteins (Figure 4). Moreover, the GCMN network contained a highly specific protein cluster, identified as the 14-3-3 protein family, whose members were expressed at significantly higher levels than in normal skin as follows: 14-3-3 sigma (or SFN, 1.7-fold) [GenBank Gene ID: 2810], 14-3-3 protein beta/alpha (YWHAB, 2.2-fold) [GenBank Gene ID: 7529], 14-3-3 protein epsilon (YWHAE, 4.2-fold) [GenBank Gene ID: 7531], 14-3-3 protein gamma (YWHAG, 2.1-fold) [GenBank Gene ID: 7532], 14-3-3 protein theta (YWHAQ, 3.3-fold) [GenBank Gene ID: 10971], and 14-3-3 protein zeta/delta (YWHAZ, 2.6-fold) [GenBank Gene ID: 7534].

\section{Comparison of systemic properties between GCMN and metastatic melanoma}

To investigate the inter-relationship between the proteomic characteristics of GCMN and melanoma, we compared our GCMN proteome network with a recently reported proteome of metastatic melanoma cell line that contained 110 non-redundant proteins [16]. We selected 63 of the total melanoma proteins that had been included in the two high-score biological networks and analyzed protein-protein interactions between the GCMN and melanoma proteomes (Figure 5A). Five 
Table 2 Abundance modified proteins in GCMN

\begin{tabular}{|c|c|c|c|c|c|}
\hline Identified proteins & Cancer implication & Accession number ${ }^{1}$ & p-Value & Fold-change & GenelD ${ }^{2}$ \\
\hline \multicolumn{6}{|c|}{ Post-translational modification, protein turnover, chaperones (15) } \\
\hline CTSD cathepsin D - & $\begin{array}{l}\text { breast [52] ovarian [53] } \\
\text { melanoma [14,15] }\end{array}$ & IPI00011229 & 0.024 & 6.8 & 1509 \\
\hline $\begin{array}{l}\text { HSP90AA1 heat shock protein } \\
\text { 90-kDa alpha (cytosolic), } \\
\text { class A member } 1 \text { isoform } 1\end{array}$ & & IPI00382470 & 0.02 & 3.4 & 3320 \\
\hline $\begin{array}{l}\text { HSP90AB1 heat shock } \\
\text { protein HSP 90-beta }\end{array}$ & & IPI00414676 & 0.013 & 3.6 & 3326 \\
\hline $\begin{array}{l}\text { HSPA1A;HSPA1B heat } \\
\text { shock 70-kDa protein } 1\end{array}$ & & IPI00304925 & 0.031 & 2.4 & 3303 \\
\hline $\begin{array}{l}\text { HSPA8 Isoform } 1 \text { of heat } \\
\text { shock cognate } 71-k D a \text { protein }\end{array}$ & & IPI00003865 & 0.0016 & 5.2 & 3312 \\
\hline HSPB1 heat shock protein beta-1 & & IPI00025512 & 0.0027 & 3.8 & 3315 \\
\hline PDIA3 protein disulfide-isomerase A3 & ovarian [54] & IPI00025252 & 0.012 & 5.4 & 2923 \\
\hline PHB prohibitin & $\begin{array}{l}\text { gastric carcinoma [28], } \\
\text { thyroid cancer }[29], \\
\text { hepatocellular carcinoma [30], } \\
\text { melanoma }[16,17]\end{array}$ & IPI00017334 & 0.025 & 5.3 & 5245 \\
\hline $\begin{array}{l}\text { PSMB1 proteasome } \\
\text { subunit beta type-1 }\end{array}$ & & IPI00025019 & 0.045 & 3.5 & 5689 \\
\hline $\begin{array}{l}\text { SFN Isoform } 1 \text { of 14-3-3 } \\
\text { protein sigma }\end{array}$ & & IPI00013890 & 0.027 & 1.7 & 2810 \\
\hline $\begin{array}{l}\text { YWHAB long isoform of } \\
\text { 14-3-3beta/alpha }\end{array}$ & & IPI00216318 & 0.0012 & 2.2 & 7529 \\
\hline YWHAE 14-3-3epsilon & & IPI00000816 & 0.0051 & 4.2 & 7531 \\
\hline YWHAG 14-3-3gamma & & IPI00220642 & 0.024 & 2.1 & 7532 \\
\hline YWHAQ 14-3-3theta & & IPI00018146 & 0.00088 & 3.3 & 10971 \\
\hline YWHAZ 14-3-3zeta/delta & & IPI00021263 & 0.0021 & 2.6 & 7534 \\
\hline \multicolumn{6}{|l|}{ Cytoskeleton (4) } \\
\hline $\begin{array}{l}\text { CAPZA1 F-actin-capping } \\
\text { protein subunit alpha-1 }\end{array}$ & & IPI00005969 & 0.0044 & 2.6 & 829 \\
\hline $\begin{array}{l}\text { CAPZB cDNA, FL93598, } \\
\text { highly similar to Homo sapiens } \\
\text { capping protein (actin filament) } \\
\text { muscle Z-line, beta }\end{array}$ & & IPI00641107 & 0.017 & 2.9 & 832 \\
\hline $\begin{array}{l}\text { Isoform } 2 \text { of dynein heavy chain 2, } \\
\text { axonemal }\end{array}$ & & IPI00651691 & 0.004 & 2.3 & 146754 \\
\hline $\begin{array}{l}\text { Isoform } 2 \text { of myosin light } \\
\text { chain kinase, smooth muscle }\end{array}$ & & IPI00221255 & 0.0018 & 2.6 & 4638 \\
\hline \multicolumn{6}{|l|}{ General function prediction only (5) } \\
\hline $\begin{array}{l}\text { CDC42 Isoform } 2 \text { of cell-division } \\
\text { control protein } 42 \text { homolog }\end{array}$ & immune escape of cancer [55] & IPI00016786 & 0.017 & 2.8 & 998 \\
\hline $\begin{array}{l}\text { CSPG4 chondroitin sulfate } \\
\text { proteoglycan } 4\end{array}$ & $\begin{array}{l}\text { melanoma, human carcinoma, } \\
\text { sarcoma [18] }\end{array}$ & IPI00019157 & 0.026 & 2.3 & 1464 \\
\hline $\begin{array}{l}\text { HNRNPA2B1 isoform B1 of } \\
\text { heterogeneous nuclear } \\
\text { ribonucleoproteins A2/B1 }\end{array}$ & glioblastoma[56] lung cancer [57] & IPI00396378 & 0.015 & 4.9 & 3181 \\
\hline $\begin{array}{l}\text { PEBP1 } \\
\text { phosphatidylethanolamine-binding } \\
\text { protein } 1\end{array}$ & $\begin{array}{l}\text { prostate [58], breast [59], } \\
\text { gastrointestinal stromal [60], } \\
\text { melanoma [19], ovarian [61] }\end{array}$ & IPI00219446 & 0.026 & 2.9 & 5037 \\
\hline $\begin{array}{l}\text { RAC1 isoform A of Ras-related C3 } \\
\text { botulinum toxin substrate } 1\end{array}$ & skin tumor [62] & IPI00010271 & 0.0092 & 3.7 & 5879 \\
\hline \multicolumn{6}{|l|}{ Carbohydrate transport and metabolism (3) } \\
\hline \multirow[t]{2}{*}{ ALDOA fructose-bisphosphate aldolase A } & & IPI00465439 & 0.034 & 4 & 226 \\
\hline & & IPI00453476 & 0.0012 & 3.1 & \\
\hline
\end{tabular}


Table 2 Abundance modified proteins in GCMN (Continued)

Uncharacterized protein

ENSP00000348237

\begin{tabular}{|c|c|c|c|c|c|}
\hline FLG2 filaggrin-2 & & IPI00397801 & 0.000021 & 0.2 & 388698 \\
\hline \multicolumn{6}{|l|}{ Energy production and conversion (2) } \\
\hline $\begin{array}{l}\text { ATP5B ATP } \\
\text { synthase subunit beta, } \\
\text { mitochondrial }\end{array}$ & & IPI00303476 & 0.032 & 5 & 506 \\
\hline $\begin{array}{l}\text { ETFA electron transfer } \\
\text { flavoprotein subunit alpha, } \\
\text { mitochondrial }\end{array}$ & & IPI00010810 & 0.0028 & 3.4 & 2108 \\
\hline \multicolumn{6}{|l|}{ Signal transduction mechanisms (3) } \\
\hline $\begin{array}{l}\text { ARHGDIA rho } \\
\text { GDP-dissociation } \\
\text { inhibitor } 1\end{array}$ & mesothelioma [63] & IPI00003815 & 0.047 & 3.4 & 396 \\
\hline FBLN5 fibulin-5 & breast cancer [64] & IPI00294615 & 0.0028 & 3.4 & 10516 \\
\hline RYR3 uncharacterized protein RYR3 & & IPI00217185 & 0.013 & 2.7 & 6263 \\
\hline \multicolumn{6}{|c|}{ Intracellular trafficking, secretion, and vesicular transport (3) } \\
\hline ANXA1 annexin A1 & breast cancer [65] & IPI00218918 & 0.03 & 3 & 301 \\
\hline ANXA2 annexin A2 isoform 1 & breast cancer [66] & IPI00418169 & 0.0059 & 1.8 & 302 \\
\hline ANXA5 annexin A5 & colorectal cancer [67] & IPI00329801 & 0.025 & 3.8 & 308 \\
\hline \multicolumn{6}{|c|}{ Amino acid transport and metabolism (2) } \\
\hline $\begin{array}{l}\text { PHGDH D-3-phosphoglycerate } \\
\text { dehydrogenase }\end{array}$ & breast cancer [68] & IPI00011200 & 0.031 & 5 & 26227 \\
\hline TPSB2 TPSB2 & & IPI00419942 & 0.043 & 2.2 & 64499 \\
\hline \multicolumn{6}{|l|}{ Lipid transport and metabolism (2) } \\
\hline $\begin{array}{l}\text { ECH1 delta(3,5)-delta(2,4)-dienoyl-CoA } \\
\text { isomerase, } \\
\text { mitochondrial }\end{array}$ & & IPI00011416 & 0.00034 & 3.1 & 1891 \\
\hline FASN fatty acid synthase & $\begin{array}{l}\text { breast cancer, } \\
\text { endometrial cancer [69] } \\
\text { prostate cancer [70] }\end{array}$ & IPI00026781 & 0.023 & 3.1 & 2194 \\
\hline
\end{tabular}

Translation, ribosomal structure, and biogenesis (2)

\begin{tabular}{|c|c|c|c|c|}
\hline $\begin{array}{l}\text { EEF1A1 elongation } \\
\text { factor 1-alpha } 1\end{array}$ & IPI00396485 & 0.012 & 2.5 & 1915 \\
\hline RPSA ribosomal protein SA, 33-kDa protein melanoma [20] & IPI00413108 & 0.024 & 2.9 & 3921 \\
\hline \multicolumn{5}{|l|}{ RNA processing and modification (1) } \\
\hline $\begin{array}{l}\text { HNRNPU short isoform } \\
\text { of heterogeneous nuclear } \\
\text { ribonucleoprotein } U\end{array}$ & IPI00479217 & 0.0037 & 2.3 & 3192 \\
\hline \multicolumn{5}{|l|}{ Cell cycle control, cell division, chromosome partitioning (1) } \\
\hline KRT1 keratin, type II cytoskeletal 1 & IPI00220327 & 0.016 & 0.7 & 3848 \\
\hline \multicolumn{5}{|l|}{ Inorganic ion transport and metabolism (1) } \\
\hline $\begin{array}{l}\text { CLIC1 chloride } \\
\text { intracellular channel } \\
\text { protein } 1 \\
\end{array}$ & IPI00010896 & 0.015 & 3.5 & 1192 \\
\hline \multicolumn{5}{|l|}{ Secondary metabolites biosynthesis, transport, and catabolism (1) } \\
\hline ADH1B alcohol dehydrogenase 1B & IPI00473031 & 0.025 & 0.2 & 125 \\
\hline \multicolumn{5}{|l|}{ Function unknown (1) } \\
\hline HRNR hornerin & IPI00398625 & 0.035 & 0.2 & 388697 \\
\hline
\end{tabular}

Accession Number ${ }^{1}$ : International Protein Index (IPI) accession number, GenelD²: NCBI GenelD.

proteins including $\mathrm{PHB}, \mathrm{CTSD}$, elongation factor 1-alpha 1 (EEF1A1), Annexin A2 (ANXA2), and heat-shock protein beta-1 (HSPB1) were similarly upregulated in both proteome sets. Subsequently, we found that 217 interactions existed between the GCMN and melanoma proteomes. To estimate the biological importance of the 


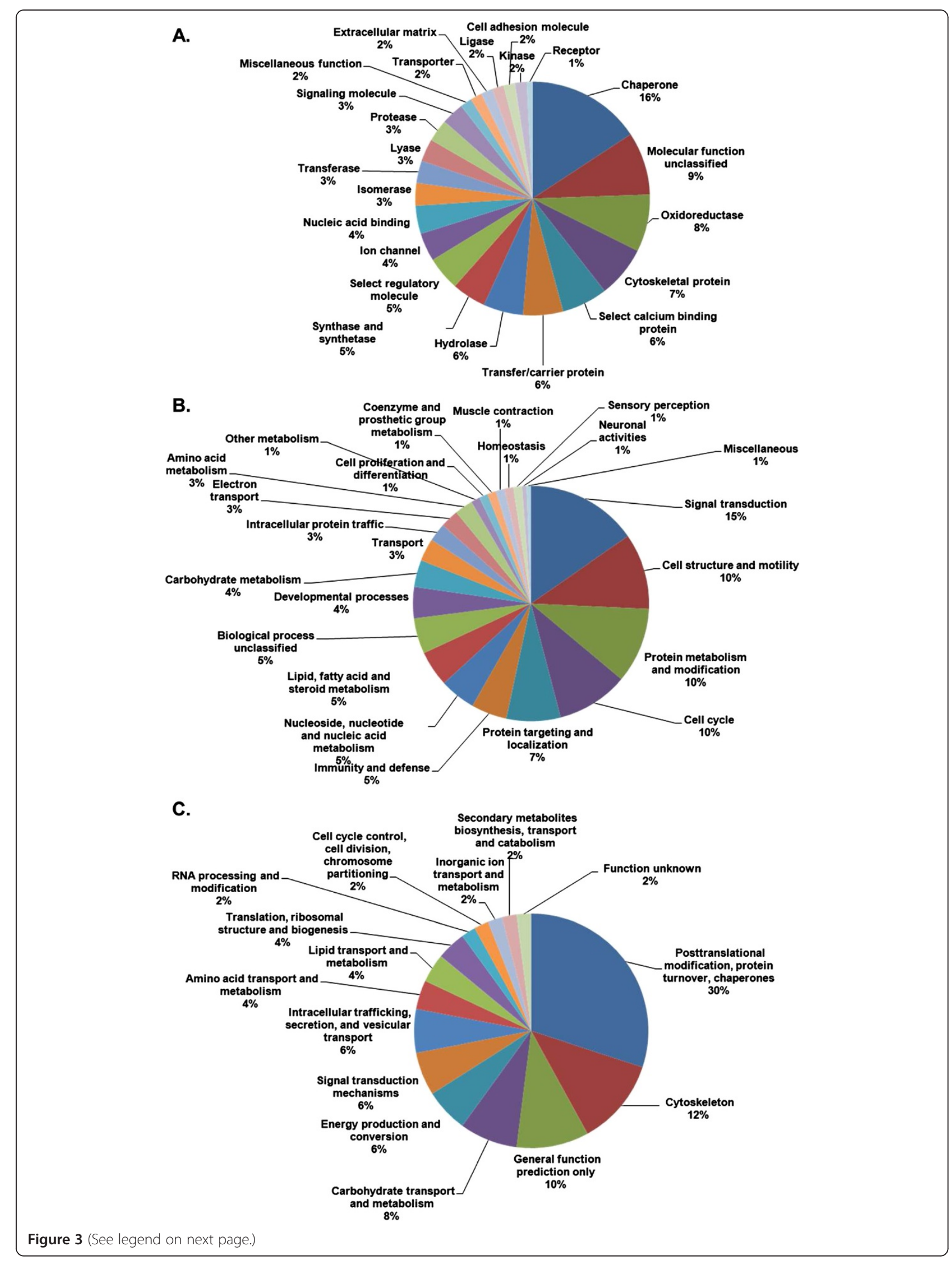


(See figure on previous page.)

Figure 3 Functional categories and their corresponding percentages in the GCMN proteome. Molecular function (A), biological process (B), and clusters of orthologous groups (COG) (C) were analyzed using the online bioinformatic tools PANTHER (http://www.pantherdb.org/) and COGnitor provided by the NCBI database (http://www.ncbi.nlm.nih.gov/COG/old/xognitor.html).

14-3-3 family proteins in the process of melanotumorigenesis, we next analyzed the protein-protein interactions of 14-3-3 family proteins with the GCMN and melanoma proteomes. We identified a total of 23 proteins, out of which 6 proteins in the GCNM and 17 proteins in the melanoma proteome possibly interacted with the 14-3-3 family proteins (Figure 5B). Two proteins interacting with 14-3-3, PHB and EEF1A1, were codetected in both GCMN and melanoma proteomes. Additionally, the average interaction number of the 14-3-3 family proteins (7.66) was 2-fold higher than the average interaction number of other proteins (3.80). These results suggest that there are similar proteomic alterations in both GCMN and metastatic melanoma and the 14-3-3 family proteins may play an important role in melanotumorigenesis and tumor progression.

\section{Validation of the abundance modified proteins}

To further validate the proteomic results, we evaluated the altered expression of 14-3-3 alpha/beta, sigma, epsilon, zeta, tau, and of prohibitin in GCMN and unpaired normal skin samples $(n=7)$ using semi-quantitative western blots. The integrated values of each protein band are reported in supplementary Additional files 4: Table S2 and Additional files 5.: Table S3 Because it was difficult to obtain skin specimens from normal children younger than 10 years of age, we could not use age- matched normal skin samples. However, we used comparatively young skin samples obtained from subjects whose average age was validated as 22.7 years. As seen in the representative western blots (Figures 6A and B), the protein expression of 14-3-3 epsilon, 14-3-3 tau, and prohibitin in GCMN samples was 1.55-fold, 2-fold, and 2.53-fold, respectively, which was significantly higher than that in normal skin samples. However, the expression of 14-3-3alpha/beta, sigma, and zeta were not significantly different in GCMN and normal skin samples. One possible explanation for the unmatched results between the results of the proteomic and western blot analysis might be the diversity of samples used in the western blot analysis, which unlike the paired samples utilized in the proteomic analysis, were collected from normal skin samples of seven non-GCMN patients.

We further analyzed the expression levels of 14-3-3 epsilon, 14-3-3 tau, and prohibitin in normal skin fibroblast cell line (Detroit 551) and three kinds of melanoma cell lines (SK-MEL-2, SK-MEL-5, and SK-MEL-28) to validate whether our proteomic findings are truly relevant to clinical melanoma. Our results showed that the protein levels of 14-3-3 epsilon were significantly increased in all melanoma cell lines, and the levels of 14-3-3 tau were significantly increased in the SK-MEL-2 and SK-MEL-28 cell lines. Additionally, the protein levels of prohibitin were increased in the SK-MEL-2 and

Table 3 Enriched functional group in GCMN

\begin{tabular}{|c|c|c|c|c|c|}
\hline Functional group & Group Genes & GOID & $\%$ Genes $^{1}$ & p-Value ${ }^{2}$ & $p$-Value/B ${ }^{3}$ \\
\hline Cell cycle & $\begin{array}{l}\text { ANXA1|SFN|YWHAB| } \\
\text { YWHAE|YWHAG|YWHAQ } \\
\text { YWHAZ }\end{array}$ & KEGG:04110 & 5.0 & $9.00 \mathrm{E}-07$ & 4.77E-05 \\
\hline $\begin{array}{l}\text { Phospholipase } \\
\text { inhibitor activity }\end{array}$ & $\begin{array}{l}\text { ANXA1|ANXA2|ANXA5| } \\
\text { ARHGDIA|ATP5B|KRT1 }\end{array}$ & GO:0004859 & 27.3 & $3.17 \mathrm{E}-06$ & $1.68 \mathrm{E}-04$ \\
\hline Melanosome & $\begin{array}{l}\text { ANXA1|ANXA2|ANXA5| } \\
\text { ATP5B|CLIC1|CTSD|FASN| } \\
\text { HRNR|HSP90AA1|HSP90AB1| } \\
\text { HSPA1B|HSPA8|HSPB1|KRT1| } \\
\text { PDIA3|RAC1|SFN|YWHAB| } \\
\text { YWHAE|YWHAG|YWHAZ }\end{array}$ & GO:004247 & 12.8 & $4.09 E-16$ & $2.17 \mathrm{E}-14$ \\
\hline $\begin{array}{l}\text { Neurotrophin } \\
\text { signaling pathway }\end{array}$ & $\begin{array}{l}\text { ACTB|ARHGDIA|CAPZA1| } \\
\text { CAPZB|CDC42|HSPB1|MYLK| } \\
\text { RAC1|SFN|YWHAB|YWHAE| } \\
\text { YWHAG|YWHAQ|YWHAZ }\end{array}$ & KEGG:04722 & 6.1 & $2.36 \mathrm{E}-09$ & $1.25 \mathrm{E}-07$ \\
\hline $\begin{array}{l}\text { Downregulated } \\
\text { of MTA-3 in } \\
\text { ER-negative } \\
\text { breast tumors }\end{array}$ & $\begin{array}{l}\text { ADH1B|ALDOA|CTSD| } \\
\text { ECH1|HSPB1|PHGDH|RYR3 }\end{array}$ & BioCarta:204 & 28.6 & 4.94E-08 & $2.62 \mathrm{E}-06$ \\
\hline Glycolysis/Gluconeogenesis & ADH1B|ALDOA|ECH1|FASN & KEGG:00010 & 4.7 & 7.23E-04 & 0.038 \\
\hline
\end{tabular}

${ }^{1} \%$ of associated genes identified in our results/total known genes involved in the function or pathway, ${ }^{2}$ Term $\mathrm{p}$-Value, ${ }^{3}$ Term $\mathrm{p}$-Value with Bonferroni correction. 


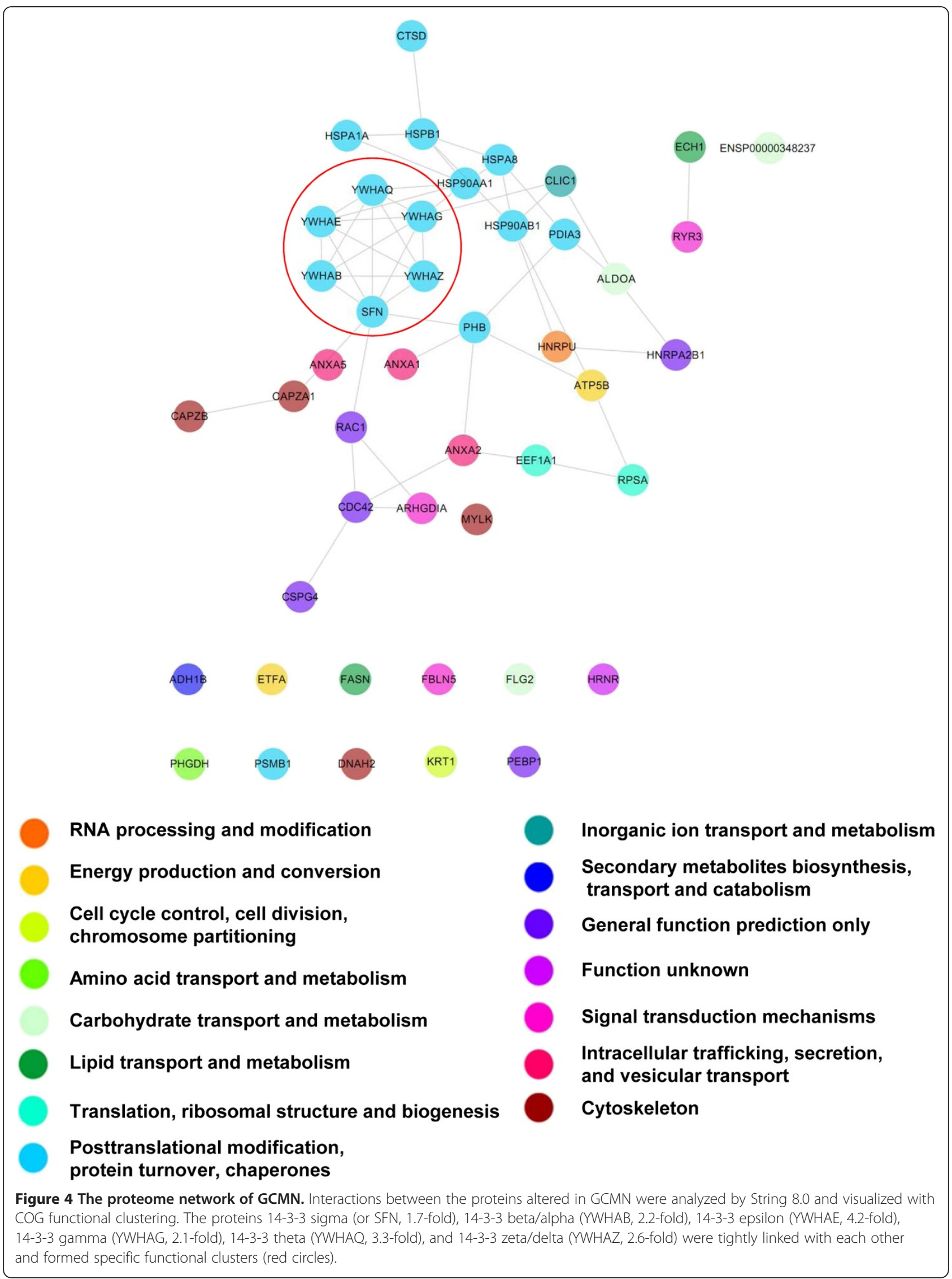




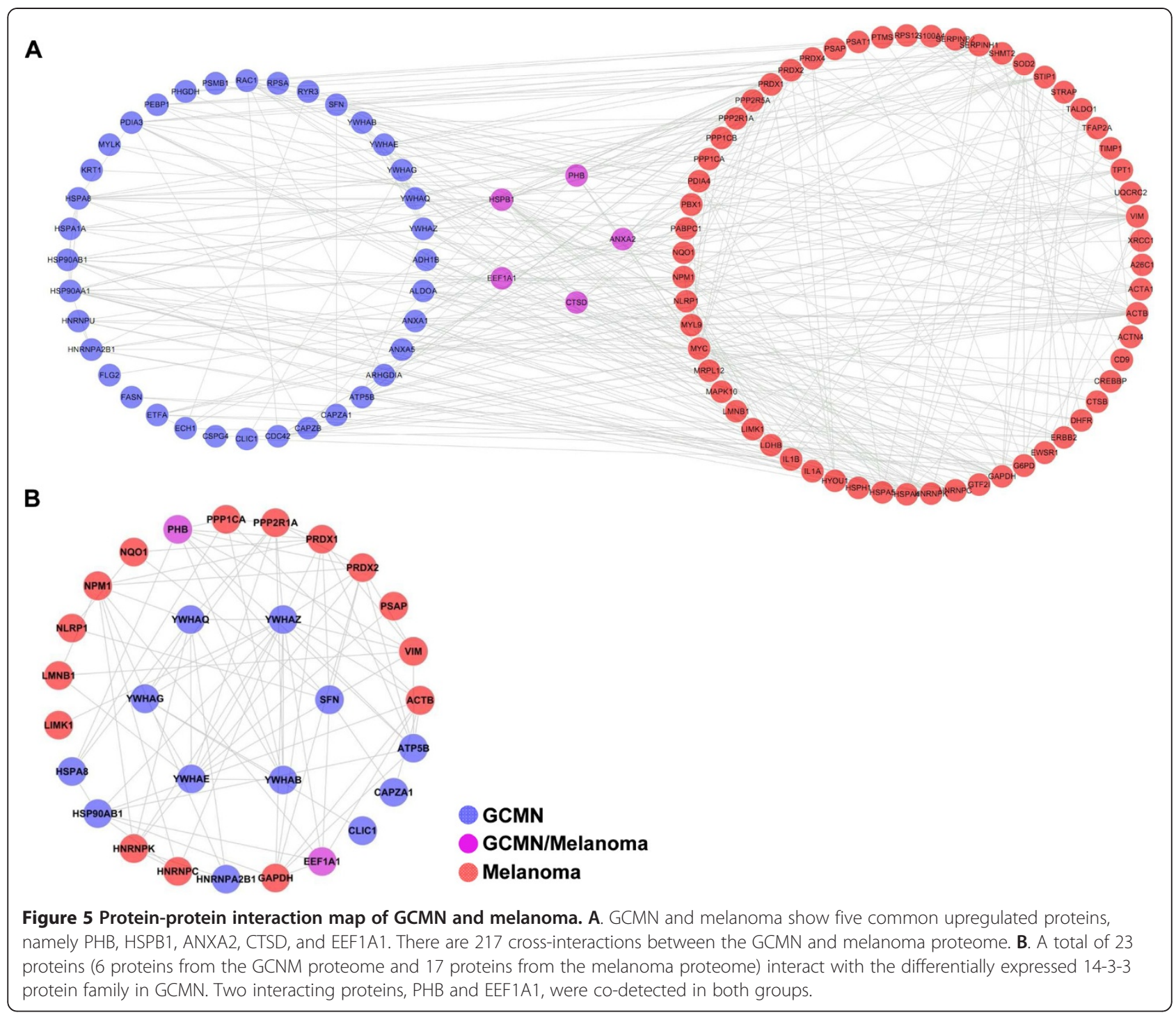

SK-MEL-5 cells, but were decreased in the SK-MEL-28 cell line (Figures 7A and B).

\section{Discussion}

In the present study, the proteomic composition of GCMN was compared with that of normal skin. A major aim of the study was the identification of proteins whose expression is altered in GCMN, which will help understand the altered biological processes in GCMN and help gain an insight into the mechanism of melanotumorigenesis in these malformations. LC-MS/MS analysis showed that 46 of the 438 identified proteins changed in their abundance levels between the normal skin and GCMN samples. In the GCMN samples, $92 \%$ of the abundance modified proteins were upregulated, but only $8 \%$ were downregulated (Figure 2 and Table 2). The use of different bioinformatic tools showed that GCMN clearly differed from normal skin in terms of protein expression patterns, which suggested that specific biological processes are altered in GCMN. As derived from the GO categories, KEGG pathways, and Reactome_biocarta, these processes were shown to encompass several major biological functions, namely the neurotrophin signaling pathway, downregulated of MTA-3 in ER-negative breast tumors, the cell cycle, phospholipase inhibitor activity, and glycolysis/gluconeogenesis. Strikingly, among these, neurotrophin signaling [17,18], MTA-3 downregulation (Table 3) [19], cell cycle deregulation [20], and glycolysis/gluconeogenesis [21] have been implicated in the development and progression of melanoma and other cancers.

Comparison of systemic properties of the GCMN and metastatic melanoma proteomes revealed that these two different disease proteomes shared at least five proteomic alterations in common and their abundance modified proteins closely interacted with each other (Figure 5A). Because closely related diseases are known to share common 


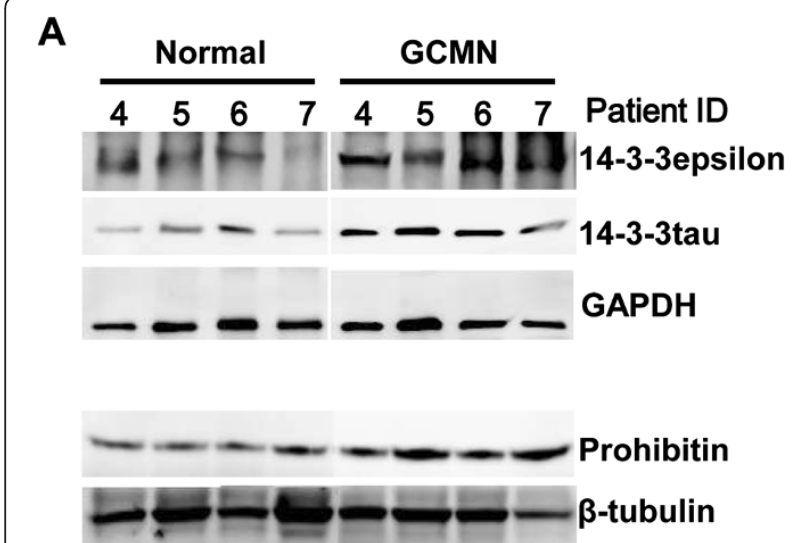

B

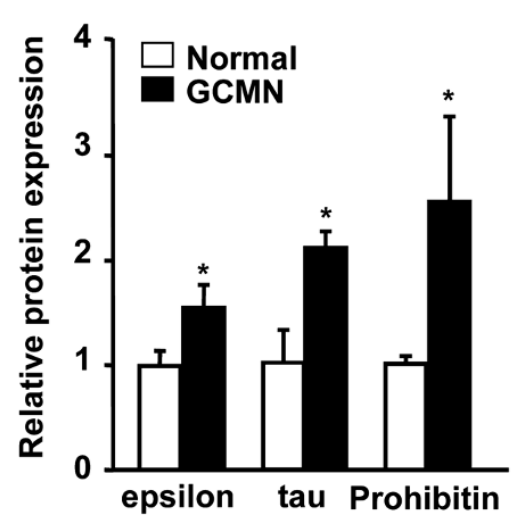

Figure 6 Validation of protein expression of the 14-3-3 protein family and PHB. A. Representative western blot images of 14-3-3 epsilon, 14-3-3 tau, and prohibitin proteins in normal and GCMN skin samples. B. The relative protein expression of 14-3-3 epsilon, 14-3-3 tau, and prohibitin was significantly increased in GCMN samples compared to normal skin samples $(n=7) .{ }^{*} p<0.05$, twotailed unpaired Student's t-test vs. normal skin sample.

proteins or common interactions [22], our results suggested the close relationship between GCMN and melanoma.

Our proteomic analysis also revealed the significantly increased expression of 14 cancer-related proteins in GCMN compared to normal skin samples. Among them, $\mathrm{PHB}$ is a molecular maker of malignant cancers, and overexpression of $\mathrm{PHB}$ has been reported in melanoma $[11,12]$ and various kinds of cancers, including gastric carcinoma [23], thyroid cancer [24], and hepatocellular carcinoma [25]. This significant upregulation of cancerrelated proteins in GCMN, specifically which of melanoma-implicated proteins, strengthened the possible risk of melanotumorigenesis in GCMN.

The 14-3-3 proteins comprise a highly conserved family of proteins whose members are found in both plants and mammals. They mediate signal transduction by binding to phosphoserine-containing proteins and are involved in many biological cellular processes, such as metabolism, protein trafficking, signal transduction,
A
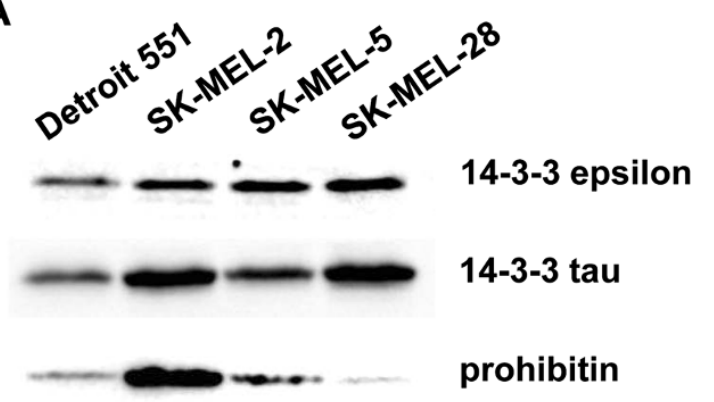

14-3-3 tau

prohibitin

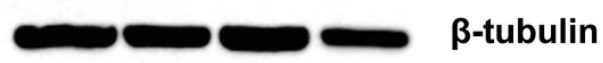

B

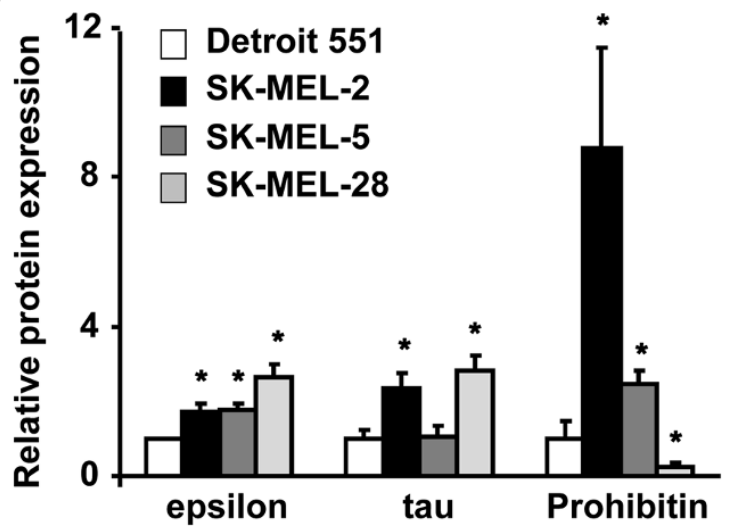

Figure 7 Validation of protein expression of the 14-3-3 protein family and PHB in normal and melanoma cell lines. A. Representative western blot images of 14-3-3 epsilon, 14-3-3 tau, and prohibitin in normal skin cells (Detroit 551) and human melanoma cell lines (SK-MEL-2, SK-MEL-5, and SK-MEL-28). B. Relative protein expression of 14-3-3 epsilon, 14-3-3 tau, and prohibitin in normal skin cells (Detroit 551) and human melanoma cell lines (SK-MEL-2, SK-MEL-5, and SK-MEL-28) ( $n=3$ for each cell lines). ${ }^{*} p<0.05$, two-tailed unpaired Student's t-test vs. Detroit 551 (normal skin cells).

apoptosis, and cell cycle regulation, through interaction with various phosphoserine-containing proteins, such as CDC25 phosphatases, RAF1, and IRS1 proteins. In the present study, 14-3-3 family proteins were estimated to interact with 23 proteins in GCMN and melanoma (Figure 5B), and their average number of interactions was about 2-fold higher than the average number of interactions of other abundance modified proteins. These results suggested that 14-3-3 family proteins could play an important role in the alteration of biological processes in GCMN and melanoma.

The 14-3-3 family proteins consist of seven isoforms: beta, gamma, epsilon, sigma, zeta, tau, and eta. The alpha and sigma isoforms are the phosphoforms of 14-3-3 beta and zeta, respectively. All 14-3-3 proteins are ubiquitously expressed, with the exception of 14-3-3 sigma, which is 
exclusively expressed in epithelial cells [26]. Among the 14-3-3 family members, the overexpression of the 14-3-3 sigma gene or its respective protein is frequently found in cancers such as ovarian carcinomas [27], pancreatic cancer [28], papillary thyroid carcinoma [29], hepatocellular carcinoma [29], and breast cancer [30]. In our proteomic analysis, the expression of 14-3-3 proteins was significantly higher in GCMN than in normal skin samples, which strongly supports the greater tendency toward melanotumorigenesis in GCMN. In particular, the enhanced expression of 14-3-3 epsilon and tau proteins was clearly shown in western blot analysis (Figure 6).

Compared to the other isoforms, little is known about the molecular and biological role of 14-3-3 tau and epsilon proteins. Like other isoforms, 14-3-3 tau is also involved in cell death and survival processes. For example, 14-3-3 tau binds to ataxia telangiectasia-mutated (ATM)phosphorylated E2F1 during DNA damage and promotes E2F1 stability, leading to the induction of apoptosis [31], and the deletion of 14-3-3 tau leads to embryonic lethality in a mouse model [32]. Interestingly, a recent study suggested that 14-3-3 tau exhibits an oncogenic role by downregulating p21 in breast cancer [33].

14-3-3 epsilon has been shown to play an essential role in cell development. Studies in Drosophila showed that 14-3-3 epsilon is required for the correct timing of mitosis in undisturbed post-blastoderm cell cycle [34]. More recently, defects in neuronal migration during the development of 14-3-3 epsilon-knockout mice were reported [35].

The phosphorylation-induced binding of 14-3-3 epsilon to the pro-apoptotic transcription factor forkhead transcription factor-like 1 (FKHRL1 or FOXO3a) leads to structural changes in 14-3-3 epsilon and inhibits its pro-apoptotic activity [36]. In inflammation and carcinogenesis, 14-3-3 epsilon interacts with key molecules of the mitogen-activated protein kinase signaling module to selectively modulate tumor necrosis factor-alphainduced nuclear factor-kappa-beta activity [37]. The function and regulatory mechanism of 14-3-3 epsilon in carcinogenesis is controversial and appears to be tumorspecific. Expression of the protein is higher in renal cell carcinoma than that in normal kidney [38]. Moreover, on the basis of their involvement in the tumorigenesis of meningioma, 14-3-3 epsilon, zeta, and theta are thought to be efficient markers for predicting the degree of malignancy of these tumors [39]. In contrast, mRNA and protein expression of 14-3-3 epsilon in laryngeal squamous cell carcinoma tissues was shown to be significantly lower than that in normal tissues [40]. An early role of 14-3-3epsilon in tumorigenesis is suggested by the observation that 14-3-3 epsilon expression is increased in intrinsically aged and photoaged human skin [41]. Interestingly, we found even higher protein levels of 14-3-3 epsilon, 14-3-3 tau, and PHB in GCMN than those in aged skin samples. This result suggested that GCMN may have a higher risk of tumorigenesis than aged skin. Because of the limitation in sample availability, we could not directly determine the expression level of 14-3-3 proteins and PHB in malignant melanoma tissue; however, we demonstrated significantly increased protein expression of 14-3-3 epsilon and tau in two different melanoma cell lines, SK-MEL-2 and SKMEL-28, compared to normal skin cell line (Detroit 551). This result might support the association of 14-3-3 epsilon and tau upregulation with clinical melanotumorigenesis (Figures 7A and $\mathrm{B}$ ).

Nevertheless, further studies are needed to validate the functional role of 14-3-3 proteins in melanotumorigenesis through the proteomic comparison of different malignant melanoma patients with giant congenital melanocytic nevi. Furthermore, it is also necessary to carefully validate the biological meaning of the upregulation of melanoma-implicated proteins in GCMN and their role in melanotumorigenesis.

\section{Conclusion}

Taken together, our data suggest that proteomic modifications with tumorigenic potential are present in GCMN, and these proteomic alterations possibly modify six important biological processes or pathways that include melanosome, neurotrophin signaling pathway, downregulated of MTA-3 in ER-negative breast tumors, cell cycle, phospholipase inhibitor activity, and glycolysis/ gluconeogenesis These pathways may be significantly altered in GCMN skins. The intensive alteration of 14-3-3 family proteins and PHB possibly acts as a central regulator of GCMN biological pathway remodeling, which may have an important role in the development of GCMN and could be associated with melanotumorigenesis.

\section{Materials and methods \\ Patients}

A total of 10 normal and GCMN skin samples, which were defatted, were obtained from patients who underwent excision procedures at the Department of Plastic Surgery, Inje University Ilsan Paik Hospital, Korea. The collection and use of the samples were approved by the Institutional Review Board of Inje University Ilsan Paik Hospital (IRB No. IB-0902-015). The present study was carried out in accordance with The Code of Ethics of the World Medical Association (Declaration of Helsinki) for experiments involving humans.

\section{Cell lines and culture conditions}

The human embryo skin cell line Detroit 551 and the human malignant melanoma cell lines SK-MEL-2, SKMEL-5, and SK-MEL-28 were obtained from the American Type Culture Collection (ATCC; Rockville, MD). The 
culture medium used throughout these experiments was RPMI-1640 (Lonza, Verviers, Belgium) containing 10\% fetal bovine serum (PAA, Pasching, Austria) and $100 \mu \mathrm{g} /$ $\mathrm{ml}$ penicillin-streptomycin (Lonza). The cells were incubated at $37^{\circ} \mathrm{C}$ in a humidified atmosphere of $5 \% \mathrm{CO}_{2}$.

\section{Sample preparation for proteomics}

Three paired normal and GCMN skin samples were selected for 1D-LC-MS/MS proteomic analysis to exclude environmental bias. Excised skin samples were ground to a powder in liquid nitrogen, dissolved in lysis buffer $(9 \mathrm{M}$ urea, $2 \mathrm{M}$ thiourea, 4\% CHAPS (3-[(3-cholamidopropyl) dimethylammonio]-1-propanesulfonate), $40 \mathrm{mM}$ dithiothreitol (DTT), and 1\% protease inhibitor cocktail), vortexed, and incubated on ice for $1 \mathrm{~h}$. The mixture was then centrifuged $\left(10,000 \times g, 30 \mathrm{~min}, 4^{\circ} \mathrm{C}\right)$, and the total proteins contained in the supernatant were used for the experiments. The total protein content of the solution was determined using the 2D Quant kit (GE Healthcare, Milwaukee, WI), with bovine serum albumin $(0-50 \mathrm{mg} / \mathrm{ml})$ as the standard.

\section{D-LC-MS/MS}

Protein separation and LC-MS analysis were performed as previously described [42]. Briefly, dissolved skin proteins were separated on a $12 \%$ polyacrylamide gel by SDS-PAGE. The gels were washed three times with $\mathrm{ddH}_{2} \mathrm{O}$ for $5 \mathrm{~min}$ each and stained with Bio-Safe Coomassie stain solution (Coomassie G250 stain; Bio-Rad, Hercules, CA) for $1 \mathrm{~h}$, with gentle shaking at room temperature. The Coomassiestained gels were evenly sliced into 15 slices and then destained by incubation in $75 \mathrm{mM}$ ammonium bicarbonate/40\% ethanol $(1: 1)$. Disulfides were reduced by treatment with $5 \mathrm{mM}$ DTT/25 mM ammonium bicarbonate at $60^{\circ} \mathrm{C}$ for $30 \mathrm{~min}$, followed by alkylation with $55 \mathrm{mM}$ iodoacetoamide at room temperature for $30 \mathrm{~min}$. The gel pieces were then dehydrated in $100 \%$ acetonitrile (ACN), dried, and swollen overnight at $37^{\circ} \mathrm{C}$ in $10 \mu \mathrm{l} 25 \mathrm{mM}$ ammonium bicarbonate buffer containing $20 \mu \mathrm{g}$ modified sequencinggrade trypsin (Roche Applied Science, Indianapolis, IN) per $\mathrm{ml}$. The tryptic peptide mixture was eluted from the gel using $0.1 \%$ formic acid. LC-MS/MS analysis was performed using a ThermoFinnigan ProteomeX workstation LTQ linear ion trap MS (Thermo Electron, San Jose, CA) equipped with a nanospray ionization (NSI) source (Thermo Electron). Briefly, $12 \mu$ l peptide sample obtained from the in-gel digestion was injected and loaded onto a peptide trap cartridge (Agilent, Palo Alto, CA). Trapped peptides were eluted onto a $10-\mathrm{cm}$ reversed-phase PicoFrit column packed in-house with $5-\mu \mathrm{m}, 300-\AA$ pore size C18 and separated by gradient elution. The mobile phases consisted of $\mathrm{H}_{2} \mathrm{O}$ and $\mathrm{ACN}$, both containing $0.1 \% \mathrm{v} / \mathrm{v}$ formic acid. The flow rate was maintained at $200 \mathrm{nl} / \mathrm{min}$. The gradient started at $2 \% \mathrm{ACN}$, then reached $60 \% \mathrm{ACN}$ in
$50 \mathrm{~min}, 80 \% \mathrm{ACN}$ in the next $5 \mathrm{~min}$, and $100 \% \mathrm{H}_{2} \mathrm{O}$ in the final $15 \mathrm{~min}$. Data-dependent acquisition $(\mathrm{m} / \mathrm{z} 400-1800)$ was enabled, and each MS survey scan was followed by five MS/MS scans within $30 \mathrm{~s}$, with the dynamic exclusion option enabled. The spray voltage was $1.9 \mathrm{kV}$, the temperature of the ion transfer tube was $195^{\circ} \mathrm{C}$, and the normalized collision energy was 35\% [42].

Data-analyzed tandem mass spectra were extracted, and the charge state was deconvoluted and deisotoped using the Sorcerer 3.4 beta2 platform (Sorcerer software 3.1.4, Sorcerer Web interface 2.2.0 r334, and Trans-, Proteomic Pipeline 2.9.5). All MS/MS samples were analyzed using SEQUEST (version v.27, rev. 11; ThermoFinnigan, San Jose, CA), which was set to search the ipiHuman 3.29 database (IPI ver.3.29, 40131 entries), with semitrypsin as the digestion enzyme. The search used a fragment-ion mass tolerance of $1.00 \mathrm{Da}$ and a parent-ion mass tolerance of 1.5 Da. Iodoacetamide-derivatized cysteine was specified as a fixed modification. Methionine oxidation, iodoacetamide derivatizion of cysteine, and phosphorylation of serine, threonine, and tyrosine were specified as variable modifications. The Scaffold software (version Scaffold-2.0; Proteome Software Inc., Portland, OR) was used to validate MS/MS-based peptide and protein identifications. Peptide identifications were accepted if their probability was $>95.0 \%$, as specified by the Peptide Prophet algorithm, and if they contained at least one identified peptide. Protein probabilities were assigned by the Protein Prophet algorithm. Proteins containing similar peptides such that they could not be differentiated based on MS/MS analysis alone were grouped to satisfy the principles of parsimony. After identifying the proteins, each dataset was used for a subtractive analysis by semi-quantitative normalized spectral counts, which were normalized by total spectral counts in the Scaffold program [43].

\section{Bioinformatics analysis}

A systemic bioinformatics analysis of the GCMN proteome was conducted using the Search Tool for the Retrieval of Interacting Genes/Proteins (STRING 8.3) [44], the Protein Analysis Through Evolutionary Relationships classification system (PANTHER 7.0) [45], the National Center for Biotechnology Information (NCBI) COG database [46], Cytoscape, and ClueGO [47].

\section{Western blot analysis}

Protein expressions of 14-3-3 alpha + beta (30 kDa), 14-3-3 epsilon (29 kDa), 14-3-3 zeta (28 kDa), 14-3-3 sigma (25 kDa), $14-3-3$ tau (31 kDa), and prohibitin (30 kDa) in normal $(\mathrm{n}=7)$ and $\mathrm{GCMN}(\mathrm{n}=7)$ samples were analyzed by western blots to confirm the proteomic results. In addition, protein expressions of 14-3-3 epsilon, 14-3-3 tau, and prohibitin in a normal cell line (Detroit 551) and 
melanoma cell lines (SK-MEL-2, SK-MEL-5, and SK-MEL28) were analyzed by western blots. Relative expression of each protein was normalized to an internal standard protein, $\beta$-tubulin $(55 \mathrm{kDa})$ or glyceraldehyde-3-phosphate dehydrogenase (37 kDa) (Abcam, Cambridge, MA). The values were expressed as mean \pm standard error.

\section{Statistical analysis}

Two-tailed unpaired Student's t-test in the Scaffold (version 2.06.02) software was used to compare abundance of each protein in the normal and GCMN skin samples. Using the Origin software (version 7.0220, OriginLabs, MA, USA), Bonferroni correction was applied to control the rate of false positives in the comparison of means of each protein's abundance. A two-tailed unpaired Student's t-test was used to compare the results of western blot analysis between the normal and GCMN skin samples. $\mathrm{p}<0.05$ was considered statistically significant.

\section{Additional files}

Additional file 1: Figure S1. Peptide mass peak of 15 slices dissected from $1 \mathrm{D}$ gels of normal skin and GCMN.

Additional file 2: Table S1. Identified proteins in skin samples of Normal and GCMN patients.

Additional file 3: Figure S2. The functional network and enriched functional group of GCMN was analyzed using ClueGO, a biological term enrichment analyzer. The following proteins were significantly enriched in GCMN: melanosome (GO_cellular component), neurotrophin signaling pathway (KEGG pathway), downregulated of MTA-3 in

ER-negative breast tumors (Biocarta), cell cycle (KEGG pathway),

phospholipase inhibitor activity (GO_molecular function), and

glycolysis/gluconeogenesis (KEGG pathway).

Additional file 4: Table S2. Integrated densitometry value of Western blot band.

Additional file 5: Table S3. Statistical analysis result of western blot.

\section{Abbreviations}

GCMN: Giant congenital melanocytic nevus; CTSD: cathepsin D;

PDIA3: Protein disulfide-isomerase A3 precursor; PHB: Prohibitin; HSPA8: Heat shock protein 70; PHGDH: D-3-phosphoglycerate dehydrogenase; ATP5B: ATP synthase subunit beta; KRT1: Cytokeratin-1; FLG2: Filaggrin; HRNR: Hornerin; ADH1B: Alcohol dehydrogenase 1B; CSPG4: Chondroitin sulfate proteoglycan 4; PEBP1: Phosphatidylethanolamine-binding protein; RPSA: Ribosomal protein SA; COG: Clusters of Orthologous Groups; STRING: Search Tool for the Retrieval of Interacting Genes/Proteins; PANTHER: Protein Analysis Through Evolutionary Relationships; KEGG: Kyoto Encyclopedia of Genes and Genomes; GO: Gene Ontology.

\section{Competing interests}

The authors declare that they have no competing interests.

\section{Author's contributions}

HKK performed the proteomic analysis including its design, coordination, analysis of the data, and drafted the manuscript. YKK provided GCMN and normal skin samples and was largely involved in the design of the study and in writing the manuscript. ISS, SRL, SHJ, MHK, and DYS performed sample preparation and western blot analysis. NK, BDR, KSK, KCT, and CGP critically revised the clinical aspect of the manuscript. JYC carried out the MS/MS proteomic analysis. JH conceived the overall experimental design and manuscript preparation. All authors read and approved the final manuscript.

\section{Acknowledgments}

This work was supported by Priority Research Centers Program and Basic Research Program through the National Research Foundation of Korea (NRF) funded by the Ministry of Education, Science and Technology (353-2009-1E00002 and 2010-0020224).

\section{Author details}

${ }^{1}$ National Research Laboratory for Mitochondrial Signaling, Department of Physiology, College of Medicine, Cardiovascular and Metabolic Disease Center, Inje University, Busan, Korea. ${ }^{2}$ Apgujung YK Plastic Surgery Center, Seoul, Korea. ${ }^{3}$ Department of Plastic and Reconstructive Surgery, College of Medicine, Yonsei University, Seoul, Korea. ${ }^{4}$ Department of Plastic and Reconstructive Surgery, National Medical Center, Seoul, Korea. ${ }^{5}$ Department of Veterinary Biochemistry, College of Veterinary Medicine, Seoul National University, Seoul 151-742, Korea.

Received: 9 April 2012 Accepted: 26 July 2012

Published: 20 August 2012

\section{References}

1. Rhodes AR, Albert LS, Weinstock MA: Congenital nevomelanocytic nevi: proportionate area expansion during infancy and early childhood. J Am Acad Dermatol 1996, 34:51-62.

2. Cramer SF: The melanocytic differentiation pathway in congenital melanocytic nevi: theoretical considerations. Pediatr Pathol 1988, 8:253-265.

3. Brooks C, Scope A, Braun RP, Marghoob AA: Dermoscopy of nevi and melanoma in childhood. Expet Rev Dermatol 2011, 6:19-34.

4. Marghoob AA, Schoenbach SP, Kopf AW, Orlow SJ, Nossa R, Bart RS: Large congenital melanocytic nevi and the risk for the development of malignant melanoma. A prospective study. Arch Dermatol 1996, 132:170-175.

5. Krengel S, Hauschild A, Schafer T: Melanoma risk in congenital melanocytic naevi: a systematic review. Br J Dermatol 2006, 155:1-8.

6. Pollock PM, Harper UL, Hansen KS, Yudt LM, Stark M, Robbins CM, Moses TY, Hostetter G, Wagner U, Kakareka J, et al: High frequency of BRAF mutations in nevi. Nat Genet 2003, 33:19-20.

7. Bauer J, Curtin JA, Pinkel D, Bastian BC: Congenital melanocytic nevi frequently harbor NRAS mutations but no BRAF mutations. J Invest Dermatol 2007, 127:179-182.

8. Stefanaki C, Antoniou C, Stefanaki K, Petrikos G, Argyrakos T, Constantinidou $\mathrm{CV}$, Karentzou O, Stratigos A, Katsambas A: Bcl-2 and Bax in congenital naevi. Br J Dermatol 2006, 154:1175-1179.

9. Bartenjev I, Rudolf Z, Stabuc B, Vrhovec I, Perkovic T, Kansky A: Cathepsin D expression in early cutaneous malignant melanoma. Int J Dermatol 2000, 39:599-602.

10. Podhajcer OL, Bover L, Bravo Al, Ledda MF, Kairiyama C, Calb I, Guerra L, Capony F, Mordoh J: Expression of cathepsin D in primary and metastatic human melanoma and dysplastic nevi. J Invest Dermatol 1995, 104:340-344.

11. Ni-Komatsu L, Orlow SJ: Identification of Novel Pigmentation Modulators by Chemical Genetic Screening. J Invest Dermato/ 2007, 127:1585-1592.

12. Huang SK, Darfler MM, Nicholl MB, You J, Bemis KG, Tegeler TJ, Wang M, Wery J-P, Chong KK, Nguyen L, et al: LC/MS-Based quantitative proteomic analysis of paraffin-embedded archival melanomas reveals potential proteomic biomarkers associated with metastasis. PLoS One 2009, 4:e4430.

13. Wang $X$, Wang $Y$, Yu L, Sakakura K, Visus C, Schwab JH, Ferrone CR, Favoino E, Koya Y, Campoli MR, et al: CSPG4 in cancer: multiple roles. Curr Mol Med 2010, 10:419-429.

14. Schuierer MM, Bataille F, Hagan S, Kolch W, Bosserhoff AK: Reduction in Raf kinase inhibitor protein expression is associated with increased Ras-extracellular signal-regulated kinase signaling in melanoma cell lines. Cancer Res 2004, 64:5186-5192.

15. Givant-Horwitz V, Davidson B, Reich R: Laminin-induced signaling in tumor cells: the role of the $M(r) 67,000$ laminin receptor. Cancer Res 2004, 64:3572-3579.

16. Han MJ, Wang H, Beer LA, Tang HY, Herlyn M, Speicher DW: A systems biology analysis of metastatic melanoma using in-depth threedimensional protein profiling. Proteomics 2010, 10:4450-4462.

17. Marchetti D, McQuillan DJ, Spohn WC, Carson DD, Nicolson GL: Neurotrophin stimulation of human melanoma cell invasion: selected enhancement of heparanase activity and heparanase degradation of specific heparan sulfate subpopulations. Cancer Res 1996, 56:2856-2863. 
18. Marchetti D, Nicolson GL: Human melanoma cell invasion: selected neurotrophin enhancement of invasion and heparanase activity. J Investig Dermatol Symp Proc 1997, 2:99-105.

19. Bruning A, Juckstock J, Blankenstein T, Makovitzky J, Kunze S, Mylonas I: The metastasis-associated gene MTA3 is downregulated in advanced endometrioid adenocarcinomas. Histol Histopathol 2010, 25:1447-1456.

20. Hanahan D, Weinberg RA: The hallmarks of cancer. Cell 2000, 100:57-70.

21. Garber K: Energy boost: The Warburg effect returns in a new theory of cancer. J Natl Cancer Inst 2004, 96:1805-1806.

22. Kanehisa M, Limviphuvadh V, Tanabe M: Knowledge-Based Analysis of Protein Interaction Networks in Neurodegenerative Diseases.; 2010.

23. Wang KJ, Wang RT, Zhang JZ: Identification of tumor markers using twodimensional electrophoresis in gastric carcinoma. World J Gastroenterol 2004, 10:2179-2183.

24. Srisomsap C, Subhasitanont P, Otto A, Mueller EC, Punyarit P, WittmannLiebold B, Svasti J: Detection of cathepsin B up-regulation in neoplastic thyroid tissues by proteomic analysis. Proteomics 2002, 2:706-712.

25. Seow TK, Ong SE, Liang RC, Ren EC, Chan L, Ou K, Chung MC: Two-dimensional electrophoresis map of the human hepatocellular carcinoma cell line, HCC-M, and identification of the separated proteins by mass spectrometry. Electrophoresis 2000, 21:1787-1813.

26. Takahashi Y: The 14-3-3 proteins: gene, gene expression, and function Neurochem Res 2003, 28:1265-1273.

27. Vakifahmetoglu H, Olsson M, Tamm C, Heidari N, Orrenius S, Zhivotovsky B: DNA damage induces two distinct modes of cell death in ovarian carcinomas. Cell Death Differ 2008, 15:555-566.

28. Guweidhi A, Kleeff J, Giese N, El Fitori J, Ketterer K, Giese T, Buchler M, Korc $M$, Friess $\mathrm{H}$ : Enhanced expression of 14-3-3sigma in pancreatic cancer and its role in cell cycle regulation and apoptosis. Carcinogenesis 2004, 25:1575-1585

29. Ito Y, Miyoshi E, Uda E, Yoshida H, Uruno T, Takamura Y, Miya A, Kobayashi K, Matsuzuka F, Matsuura N, et al: 14-3-3 sigma possibly plays a constitutive role in papillary carcinoma, but not in follicular tumor of the thyroid. Cancer Lett 2003, 200:161-166.

30. Ferguson A, Evron E, Umbricht C, Pandita T, Chan T, Hermeking H, Marks J, Lambers A, Futreal P, Stampfer M, Sukumar S: High frequency of hypermethylation at the 14-3-3sigma locus leads to gene silencing in breast cancer. Proc Natl Acad Sci USA 2000, 97:6049-6054.

31. Wang B, Liu K, Lin F-T, Lin W-C: A Role for 14-3-3 $\mathrm{\tau}$ in E2F1 Stabilization and DNA Damage-induced Apoptosis. J Biol Chem 2004, 279:54140-54152.

32. Lau JMC, Jin X, Ren J, Avery J, DeBosch BJ, Treskov I, Lupu TS, Kovacs A, Weinheimer C, Muslin AJ: The 14-3-3т Phosphoserine-binding protein is required for cardiomyocyte survival. Mol Cell Biol 2007, 27:1455-1466.

33. Wang B, Liu K, Lin H-Y, Bellam N, Ling S, Lin W-C: 14-3-3t Regulates Ubiquitin-Independent Proteasomal degradation of p21, a novel mechanism of p21 downregulation in breast cancer. Mol Cell Biol 2010, 30:1508-1527.

34. Su TT, Parry DH, Donahoe B, Chien CT, O'Farrell PH, Purdy A: Cell cycle roles for two 14-3-3 proteins during Drosophila development. J Cell Sci 2001, 114:3445-3454.

35. Toyo-oka K, Shionoya A, Gambello MJ, Cardoso C, Leventer R, Ward HL, Ayala R, Tsai LH, Dobyns W, Ledbetter D, et al: 14-3-3epsilon is important for neuronal migration by binding to NUDEL: a molecular explanation for Miller-Dieker syndrome. Nat Genet 2003, 34:274-285.

36. Brunet A, Kanai F, Stehn J, Xu J, Sarbassova D, Frangioni JV, Dalal SN DeCaprio JA, Greenberg ME, Yaffe MB: 14-3-3 transits to the nucleus and participates in dynamic nucleocytoplasmic transport. J Cell Biol 2002, 156:817-828.

37. Zuo S, Xue Y, Tang S, Yao J, Du R, Yang P, Chen X: 14-3-3 Epsilon Dynamically Interacts with Key Components of Mitogen-Activated Protein Kinase Signal Module for Selective Modulation of the TNF-a-Induced Time Course-Dependent NF-kB Activity. J Proteome Res 2010, 9:3465-3478

38. Liang $S$, Xu Y, Shen G, Liu Q, Zhao X, Xu Z, Xie X, Gong F, Li R, Wei Y: Quantitative protein expression profiling of 14-3-3 isoforms in human renal carcinoma shows 14-3-3 epsilon is involved in limitedly increasing renal cell proliferation. Electrophoresis 2009, 30:4152-4162.

39. Liu Y, Tian RF, Li YM, Liu WP, Cao L, Yang XL, Cao WD, Zhang X: The expression of seven 14-3-3 isoforms in human meningioma. Brain Res 2010, 1336:98-102
40. Che XH, Chen H, Xu ZM, Shang C, Sun KL, Fu WN: 14-3-3epsilon contributes to tumour suppression in laryngeal carcinoma by affecting apoptosis and invasion. BMC Cancer 2010, 10:306.

41. Choi K-C, Lee S, Kwak SY, Kim M-S, Choi HK, Kim KH, Chung JH, Park SH: Increased expression of 14-3-3 [var epsilon] protein in intrinsically aged and photoaged human skin in vivo. Mech Ageing Dev 2005, 126:629-636.

42. Park HJ, Kim BG, Lee SJ, Heo SH, Kim JY, Kwon TH, Lee EB, Ryoo HM, Cho JY Proteomic profiling of endothelial cells in human lung cancer. J Proteome Res 2008, 7:1138-1150

43. Narayanasamy A, Ahn JM, Sung HJ, Kong DH, Ha KS, Lee SY, Cho JY: Fucosylated glycoproteomic approach to identify a complement component 9 associated with squamous cell lung cancer (SQLC). J Proteomics 2011, 74:2948-2958.

44. Jensen $\amalg$, Kuhn M, Stark M, Chaffron S, Creevey C, Muller J, Doerks T, Julien $P$, Roth A, Simonovic M, et al: STRING 8--a global view on proteins and their functional interactions in 630 organisms. Nucleic Acids Res 2009, 37:D412-D416.

45. Mi H, Dong Q, Muruganujan A, Gaudet P, Lewis S, Thomas PD: PANTHER version 7: improved phylogenetic trees, orthologs and collaboration with the Gene Ontology Consortium. Nucl Acids Res 2010, 38:D204-D210.

46. Tatusov RL, Fedorova ND, Jackson JD, Jacobs AR, Kiryutin B, Koonin EV, Krylov DM, Mazumder R, Mekhedov SL, Nikolskaya AN, et al: The COG database: an updated version includes eukaryotes. BMC Bioinformatics 2003, 4:41.

47. Bindea G, Mlecnik B, Hackl H, Charoentong P, Tosolini M, Kirilovsky A, Fridman W-H, Pages F, Trajanoski Z, Galon J: ClueGO: a Cytoscape plug-in to decipher functionally grouped gene ontology and pathway annotation networks. Bioinformatics 2009, 25:1091-1093.

doi:10.1186/1477-5956-10-50

Cite this article as: Kim et al: Human giant congenital melanocytic nevus exhibits potential proteomic alterations leading to melanotumorigenesis. Proteome Science 2012 10:50.

\section{Submit your next manuscript to BioMed Central and take full advantage of:}

- Convenient online submission

- Thorough peer review

- No space constraints or color figure charges

- Immediate publication on acceptance

- Inclusion in PubMed, CAS, Scopus and Google Scholar

- Research which is freely available for redistribution 